\title{
DEVELOPMENT OF MODE CHOICE MODELS USING MULTINOMIAL LOGIT APPROACH IN HYDERABAD CITY
}

\author{
G. Tejaswi ${ }^{1}$, S. Amarendra Kumar ${ }^{2}$, Aramesh $^{3}$, M. Kumar ${ }^{4}$ \\ ${ }^{l}$ PG student, Dept. of Civil Engineering, VNR Vignana Jyothi Institute of Engineering and Technology, Hyderabad, \\ Telangana, India.gangishettitejaswi@gmail.com \\ ${ }^{2}$ General Manager (Traffic), HBS Infra, Hyderabad, \\ amarendra123@gmail.com \\ ${ }^{3}$ Associate Professor, Dept. of Civil Engineering, VNR Vignana Jyothi Institute of Engineering and Technology, \\ Hyderabad, Telangana, India. aramesh28@gmail.com \\ ${ }^{4}$ Professor, Dept. of Civil Engineering, University College of Engineering Osmania University, Hyderabad, \\ Telangana, India, kumartrans@gmail.com
}

\begin{abstract}
Modesplitis the process of separating person trips by mode of travel.Choice of particular mode of a commuter affects efficiency of travel within the trip performed. This paper initially explains on factors influencing mode choice behavior in metropolitan city, Hyderabad. Multinomial logistic regression model was used for evaluation of influencing factors in mode choice behavior. A stretch of $10 \mathrm{~km}$ from Bachupally to Mallampet in Hyderabad city of Telangana State was considered for the study. The socio economic data was collected by performing home interview survey on sample basis. Factors like age, income, travel time and travel cost are considered in generating the model.

It is observed from the results that preference to public transport is more compared to all other modes of travel. Increase in travel time and travel cost per distance travelled increases in cost of operation which is primary cause for commuters to switch from personalized transport to public transport facility. The model developed for mode choice is significant at 95\% having a $R^{2}$ of 0.875.This model will certainly facilitate transport planners in identification of mode choice by the commuters in the locality and to formulate effective transport policies for improvement of transportation facility within the city.
\end{abstract}

Key words: Mode choice, multinomial logistic regression, travel time, travel cost.

\section{INTRODUCTION}

Modern life is providing traffic congestion problems to the commuter on urban streets. This is because of improper road width and irregular traffic behavior on road. To reduce the effect of traffic congestion is required to understand the importance of mode choice behavior in context of metropolitan cities like Hyderabad. Mode choice is an important criterion which affects traffic congestion. Mode choice modeling is an integral part of travel demand estimation. The choice of transport mode is probably one of the most important models in transport planning. Mode choice is the process of separating person trips by mode of travel. Accelerated industrialization throughout the world has led to higher growth rates, increased income and high demand for mobility. Increasing number of vehicles in city causes congestion and environmental problems that lead to disrupted traffic conditions like delay, accidents which cause huge economic loss to the nation. To alleviate such deteriorating transportation conditions researchers have carried out studies to understand the relationship between mode choice and various factors affecting it.

\subsection{Objectives}

- To identify the various variables that influences the mode choice behavior.

- To develop mathematical model using multinomial logistic regression for mode choice behavior.

\section{LITERATURE REVIEW}

Mode choice behavior is an important stage in urban transportation planning. To understand the relation between mode choice and the factors influencing the mode choice behavior various researchers have carried under heterogeneous traffic condition. A few authors who have contributed on mode choice analysis are discussed below. Murthy (1987) had carried mode split analysis by using log linear model and logit models .He considered all modes of transport and found that truck mode dominates over rail in transporting all commodities. He also proposed the most statistical method to analyze vast data required in transportation planning. Ghareib (1996) had carried mode split analysis for two transit modes operating in different cities of Saudi and stated that probit models are complicated 
when analyzing the situation of a binary mode choice because logit model shows more accurate predictions. Espino et al., (2007) had analysed choice of mode in sub urban corridors using nested logit models and stated that private car contributes greater percentage than all other modes. Yang et al., (2010) had done mode split analysis to get the relation between fare and mode of travel based on various parameters like trip time, cost, gender, age, occupation, income and trip intention etc. They described the effect of fare on traffic structure. Yin et al (2012) had done public transit choice behaviour model that draws on existing models. They provided the basis for urban transport planning and public transit management decision-making for improving the urban public transport split rate. Celik and Oktay (2013) had carried a multinomial logit analysis to determine the risk factors affecting severity of traffic injuries. The results shown that cars or private vehicles or those occurring during evening peak, under clear weather conditions or presence of traffic lights decrease the probability of fatal injuries

\section{METHODOLOGY}

Step1: selection of Study area.

A stretch of $10 \mathrm{~km}$ from Bachupally village to Mallampet village in Qutbullapur Mandal, Hyderabad is chosen as a study area. This area is comprised of different income categories, different travel modes, etc. Study area is shown in figure 1 .

Step 2: Data collection.

About 100 home interview surveys were done using systematic sampling technique for every 30 the house in the study. The questionnaire for survey contains the trip (such as, travel mode, purpose of trip, origin, desired destination, and length of stay at destination), the features of travelers (which includes, age, gender, monthly family income, vehicle ownership), travel time and travel cost are also included. The questionnaires were written with the names of the three distinct modes under study, such as 2 wheeler, 4 wheeler and public transport. Table 1 shows the data collected in mallampet area.

\section{Table 1 Here}

Step 3: Development of model.

For the purpose of mode split analysis, the data of commuters is collected. Percentage share of each mode is shown in table 2 and figure 2 . In this study gender, income, travel time and travel cost are four variables used in explaining the selection of mode for transportation commodities. By considering these variables multinomial logistic regression is developed using SPSS.

The designing of mode choice model needs extensive evaluation of observed data and the efficiency of whole model system. Various parameters were assessed as follows: the monthly income(I) was assessed in rupees and built in a scale as ( 0 for $<30,000$ and 1 for $>30,000$ ). The $\operatorname{gender}(G)$ was categorized as 0 for female and 1 for male.travel time(TT) was assessed in minutes and built in a scale as ( 0 for $<20$ and 1 for >20).travel cost(TC) was assessed in rupees and built in scale as ( 0 for $<20$ and 1 for $>20$ ).

\section{Table 2 Here}

A multinomial logistic regression model is designed defining three categories such as 2 wheeler 4 wheeler and public transport. In this model dependent variable is 0 for 2 wheeler, 1 for 4 wheeler and 2 for public transport. The coefficients were estimated by fitting the data in to the model. The estimated coefficients were shown in table 3 .

\section{Table 3 Here}

Step 4: calibration and validation of the model.

In the sample of 100 only 70 were used for developing the model and remaining were used for calibration and validation of model. The validation of model was evaluated by comparing similarities in observed and predicted choices. Validation of model is shown in table 4.

\section{Table 4 Here \\ 4. DATA ANALYSIS AND RESULTS}

Data was collected by home interview surveys and is shown in table 1.sample of 100 was taken for development of model. Variables considered in analysis were gender, income, travel time and travel cost. The following are the models developed by multinomial logistic regression.

(P) ${ }_{2 \mathrm{w}}=-0.298+0.170(\mathrm{G})+0.163(\mathrm{TT})-0.009(\mathrm{TC})-0.067(\mathrm{I})$ ... (i)

(P) ${ }_{4 \mathrm{w}}=-0.384+0.013(\mathrm{G})-0.370(\mathrm{TT})+0.024(\mathrm{TC})+0.828(\mathrm{I})$ ... (ii)

The results from the survey indicated that the majority of commuters use public transport for work trips; in contrast social and personal work trips were carried out using 2wheeler and 4-wheeler.

\section{CONCLUSION}

The summary of estimations using multinomial logistic regression in shown in Table 2.from the literature it has been found that income, travel time and travel cost play important role in decision of mode choice. The coefficients of gender was positive indicates females are more likely to use public transport than all other modes. The income of a person is a direct determinant of the expenses he is prepared to incur on a journey. Higher income groups are able to purchase and maintain private cars, and thus private car trips are more frequent as the income increases. The income coefficient for 2-wheeler is negative that implies it has high significance and as much influence on 4 - wheeler. This indicates that higher income groups are more likely to use 4- wheeler.

\section{REFERENCES}

[1]. Chatterjee A and Sinha "Mode Choice for Small Urban Areas" Transportation Engineering Journal, ASCE, 1957 Vol. 101.

[2]. Murthy et al., "Modal split analysis using logit models" Journal of Transportation Engineering. (1987) 113:502-519.

[3]. Ghareib "Evaluation of logit and probit models in 
mode-choice situation" Journal of transportation engineering (1996) 122:282-290.

[4]. Espino et al., "Understanding sub urban travel demand: flexible modeling with Revealed and stated choice data". Transportation research part A (2007)899-912.

[5]. Yang et al., "Research and Application of CrossNested Logit Model in Traffic Mode-Split” Plan build, and Manage Transportation Infrastructure in China (2010) 203-212.

[6]. Celik and Oktay "A Multinomial logit analysis of risk factors influencing road traffic injury severities in the Erzurum and Kars provinces of Turkey" Accident analysis and prevention (2013)72 66-77.

[7]. Bhat, C.R "Simulation estimation of mixed discrete choice models using randomized and scrambled Holton sequences". Transportation Research Part B 37 (2003) 837-855

[8]. Davidson P.W and Collins T.A, Fundamentals of Discrete Choice Models-Multinomial

[9]. Logit Model (MNL), Traffic Engineering and Control (TEC), October 2008 issue.

\section{.LIST OF TABLES}

Table 1 Sample data collection

\begin{tabular}{|l|l|l|l|l|l|}
\hline $\begin{array}{l}\text { Family } \\
\text { size }\end{array}$ & $\begin{array}{l}\text { Inco } \\
\text { me }\end{array}$ & $\begin{array}{l}\text { Mode } \\
\text { used }\end{array}$ & $\begin{array}{l}\text { Travel } \\
\text { Time }\end{array}$ & $\begin{array}{l}\text { Travel } \\
\text { Cost }\end{array}$ & $\begin{array}{l}\text { Gen } \\
\text { der }\end{array}$ \\
\hline 4 & 0 & 0 & 1 & 1 & 0 \\
\hline 3 & 0 & 0 & 1 & 1 & 1 \\
\hline 4 & 1 & 1 & 1 & 1 & 0 \\
\hline 4 & 0 & 0 & 1 & 1 & 1 \\
\hline 4 & 1 & 1 & 1 & 0 & 1 \\
\hline 2 & 0 & 0 & 1 & 1 & 1 \\
\hline 2 & 1 & 1 & 1 & 1 & 1 \\
\hline 3 & 1 & 1 & 1 & 1 & 1 \\
\hline 3 & 0 & 0 & 1 & 0 & 0 \\
\hline 2 & 1 & 1 & 1 & 1 & 0 \\
\hline 3 & 0 & 0 & 1 & 1 & 0 \\
\hline 3 & 0 & 2 & 1 & 0 & 0 \\
\hline 4 & 0 & 2 & 0 & 1 & 1 \\
\hline
\end{tabular}

In the above table data is coded in terms of 0 and 1.Income is coded as 0 for $<30,000$ and 1 for $>30,000$. Gender is considered as 0 for female and 1 for male. Travel time is coded as 0 for $<20$ minutes and 1 for $>20$ minutes. Travel cost is coded as 0 for $<20$ and 1 for $>20$ and mode used is coded as 0 for 2 -wheeler, 1 for 4 -wheeeler and 2 for public transport.
Table 2 Data analysis in development of model

\begin{tabular}{|l|l|l|}
\hline Mode & $\begin{array}{l}\text { No of } \\
\text { vehicle }\end{array}$ & $\begin{array}{l}\text { Marginal } \\
\text { Percentage }\end{array}$ \\
\hline 2w & 28 & $28.0 \%$ \\
\hline $4 \mathrm{w}$ & 42 & $42.0 \%$ \\
\hline Public Transport & 30 & $30.0 \%$ \\
\hline
\end{tabular}

Table 3: Mode choice model developed using multinomial

\begin{tabular}{|c|c|c|c|c|c|c|c|}
\hline \multirow{2}{*}{\multicolumn{2}{|c|}{$\begin{array}{l}\text { Mode of } \\
\text { transport }\end{array}$}} & \multirow{2}{*}{ B } & \multirow{2}{*}{$\begin{array}{l}\text { Std. } \\
\text { Err } \\
\text { or }\end{array}$} & \multirow{2}{*}{$\begin{array}{l}\text { Wa } \\
\text { ld }\end{array}$} & \multirow{2}{*}{$\begin{array}{l}\text { Degre } \\
\text { es of } \\
\text { freed } \\
\text { om }\end{array}$} & \multicolumn{2}{|c|}{$\begin{array}{l}95 \% \\
\text { Confidence } \\
\text { Interval for } \\
\operatorname{Exp}(B)\end{array}$} \\
\hline & & & & & & Low & Upp \\
\hline \multirow[t]{5}{*}{$\begin{array}{l}2 \\
W\end{array}$} & $\begin{array}{l}\text { Interc } \\
\text { ept }\end{array}$ & $\begin{array}{l}- \\
0.2 \\
98\end{array}$ & $\begin{array}{l}1.17 \\
4\end{array}$ & $\begin{array}{l}0.0 \\
64\end{array}$ & 1 & & \\
\hline & $\mathrm{G}$ & $\begin{array}{l}0.1 \\
7\end{array}$ & $\begin{array}{l}0.44 \\
4\end{array}$ & $\begin{array}{l}0.1 \\
47\end{array}$ & 1 & $\begin{array}{l}0.49 \\
7\end{array}$ & $\begin{array}{l}2.82 \\
9\end{array}$ \\
\hline & $\mathrm{TT}$ & $\begin{array}{l}0.1 \\
63 \\
\end{array}$ & $\begin{array}{l}0.44 \\
5 \\
\end{array}$ & $\begin{array}{l}0.1 \\
34\end{array}$ & 1 & $\begin{array}{l}0.49 \\
2\end{array}$ & $\begin{array}{l}2.81 \\
6 \\
\end{array}$ \\
\hline & $\mathrm{TC}$ & $\begin{array}{l}- \\
0.0 \\
09 \\
\end{array}$ & $\begin{array}{l}0.45 \\
6\end{array}$ & 0 & 1 & $\begin{array}{l}0.40 \\
5\end{array}$ & $\begin{array}{l}2.42 \\
3\end{array}$ \\
\hline & I & $\begin{array}{l}- \\
0.0 \\
67\end{array}$ & $\begin{array}{l}0.46 \\
1\end{array}$ & $\begin{array}{l}0.0 \\
21\end{array}$ & 1 & $\begin{array}{l}0.37 \\
9\end{array}$ & $\begin{array}{l}2.30 \\
6\end{array}$ \\
\hline \multirow[t]{5}{*}{$\begin{array}{l}4 \\
W\end{array}$} & $\begin{array}{l}\text { Interc } \\
\text { ept }\end{array}$ & $\begin{array}{l}- \\
0.3 \\
84\end{array}$ & $\begin{array}{l}1.07 \\
8\end{array}$ & $\begin{array}{l}0.1 \\
27\end{array}$ & 1 & & \\
\hline & $\mathrm{G}$ & $\begin{array}{l}0.0 \\
13 \\
\end{array}$ & 0.41 & $\begin{array}{l}0.0 \\
01 \\
\end{array}$ & 1 & $\begin{array}{l}0.45 \\
3 \\
\end{array}$ & $\begin{array}{l}2.26 \\
4 \\
\end{array}$ \\
\hline & TT & $\begin{array}{l}- \\
0.3 \\
7\end{array}$ & $\begin{array}{l}0.41 \\
4\end{array}$ & $\begin{array}{l}0.7 \\
99\end{array}$ & 1 & $\begin{array}{l}0.30 \\
7\end{array}$ & $\begin{array}{l}1.55 \\
5\end{array}$ \\
\hline & $\mathrm{TC}$ & $\begin{array}{l}0.0 \\
24 \\
\end{array}$ & $\begin{array}{l}0.42 \\
2 \\
\end{array}$ & $\begin{array}{l}0.0 \\
03\end{array}$ & 1 & $\begin{array}{l}0.44 \\
8 \\
\end{array}$ & $\begin{array}{l}2.34 \\
1 \\
\end{array}$ \\
\hline & I & $\begin{array}{l}0.8 \\
28\end{array}$ & $\begin{array}{l}0.41 \\
6\end{array}$ & $\begin{array}{l}3.9 \\
68\end{array}$ & 1 & $\begin{array}{l}1.01 \\
3\end{array}$ & $\begin{array}{l}5.16 \\
8\end{array}$ \\
\hline
\end{tabular}

G- Gender; TT-Travel Time; TC-Travel Cost; IMonthly Income

Table 4 Validation of model

\begin{tabular}{|l|l|l|l|l|}
\hline Observed & \multicolumn{2}{l}{ Predicted } & Percent correct \\
\hline & 1 & 2 & 3 & \\
\hline 1 & 28 & 45 & 0 & $56.20 \%$ \\
\hline 2 & 42 & 56 & 0 & $84 \%$ \\
\hline 3 & 30 & 28 & 0 & $0 \%$ \\
\hline & & & & \\
$\begin{array}{l}\text { Overall } \\
\text { Percentage }\end{array}$ & $44.20 \%$ & $55.80 \%$ & $0 \%$ & $69.50 \%$ \\
\hline
\end{tabular}




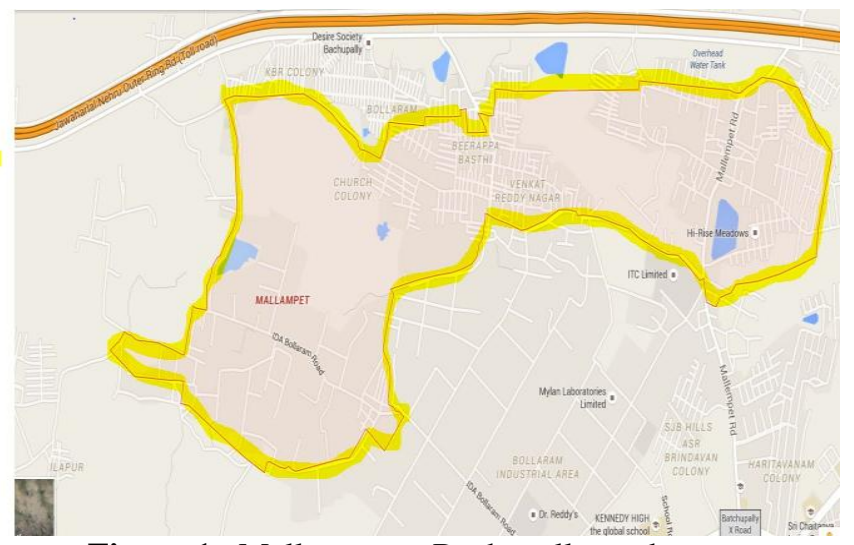

Figure 1 Mallampet to Bachupally study area

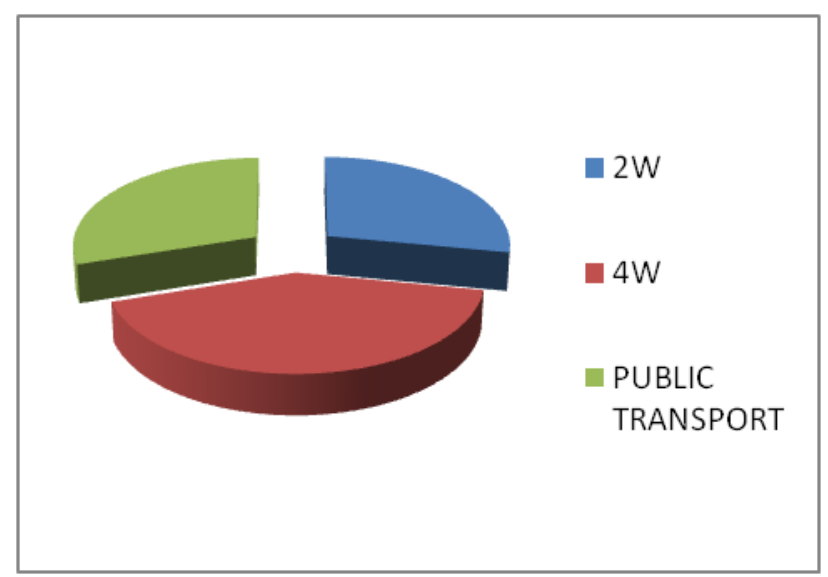

Figure 2 showing the percentage share of each mode in mallampet village. 